\title{
Allometric Equations for Predicting Biomass of Daniellia oliveri (Rolfe) Hutch. \& Dalz. Stands in the Sudano-Guinea Savannahs of Ngaoundere, Cameroon
}

\author{
Tchindebe Alexandre ${ }^{1,}$, , Ibrahima Adamou ${ }^{1}$, Tchobsala ${ }^{2}$, Mohamadou Laminou Mal Amadou ${ }^{1}$ \\ ${ }^{1}$ Department of Biological Sciences, Faculty of Sciences, the University of Ngaoundere, Ngaoundere, Cameroon \\ ${ }^{2}$ Department of Biological Sciences, Faculty of Sciences, University of Maroua, Maroua, Cameroon
}

Email address:

Tchindbalexandre@yahoo.fr (T. Alexandre)

*Corresponding author

To cite this article:

Tchindebe Alexandre, Ibrahima Adamou, Tchobsala, Mohamadou Laminou Mal Amadou. Allometric Equations for Predicting Biomass of Daniellia oliveri (Rolfe) Hutch. \& Dalz. Stands in the Sudano-Guinea Savannahs of Ngaoundere, Cameroon. Ecology and Evolutionary Biology. Vol. 4, No. 2, 2019, pp. 15-22. doi: 10.11648/j.eeb.20190402.11

Received: April 27, 2019; Accepted: June 18, 2019; Published: August 10, 2019

\begin{abstract}
Allometric relationships for estimating biomass of Daniellia oliveri (Rolfe) Hutch \& Dalz. stand were investigated in the sudano-guinea savannah of Ngaoundere, Cameroon. A total of 17 individual trees from Daniellia oliveri were harvested in Bini-Dang savannah across a range of diameter classes, from 5 to $40 \mathrm{~cm}$. Diameter at breast height (D) and total height $(\mathrm{H})$ were determined and considered as predictor variables, while total above-ground biomass, stem, branch, leaf and root biomass were the output variables of the allometric models. Among many models tested, the best ones were chosen according to the coefficient of determination adjusted ( $\mathrm{R}^{2} \mathrm{adj}$ ), the residual standard error (RSE) and the Akaike Information Criteria. The main results showed that the multiplication of tree $\mathrm{H}$ with $\mathrm{D}$ in the allometric equation did not improve in the degree of fitness of the allometric equations, except for leaf biomass. The fit allometric biomass of Daniellia oliveri model for leaf, branch, stem and root biomass and above ground biomass were the follow: $\operatorname{Ln}(\mathrm{Bl})=3.0303+0.744 * \operatorname{Ln}\left(\mathrm{D}^{2} \mathrm{H}\right) ; \operatorname{Ln}(\mathrm{Bb})=$ $3.772+2.701 * \operatorname{Ln}(\mathrm{D}) ; \operatorname{Ln}(\mathrm{Bs})=2.663+2.218 * \operatorname{Ln}(\mathrm{D}), \operatorname{Ln}(\mathrm{Br})=2.072+1.920 * \operatorname{Ln}(\mathrm{D})$ and $\operatorname{Ln}(\mathrm{Bt})=-2.089+2.374 * \operatorname{Ln}(\mathrm{D})$ respectively. The root biomass represented on average $28 \%$ of the total aboveground biomass and these two biomasses were positively and significantly correlated $(\mathrm{r}=0.93, \mathrm{p}<0.05$ and $\mathrm{n}=11)$. For the Daniellia oliveri stands studied, the diameter at breast height (D) alone showed a very strong accuracy of estimation. It is concluded that the use of tree height in the allometric equation can be neglected for the species, as far as the present study area is concerned. Therefore, for estimating the biomass of Daniellia oliveri, the use of $\mathrm{D}$ as an independent variable in the allometric equation with a power equation would be recommended. The paper describes details of tree biomass allometry, which is important in carbon stock, sylviculture and savannah management.
\end{abstract}

Keywords: Allometry, Regression, Biomass, Daniellia oliveri, Savannah of Ngaoundere, Cameroon

\section{Introduction}

Daniellia oliveri (Rolfe) Hutch \& Dalz. is a species of the Caesalpiniaceae family of the Adamawa sudano-guinea savannahs [1], playing many roles in the production systems of this region [2]. In addition to its ecological and economic functions, it has social and cultural meanings in the northern part of Cameroon. As sources of fodder, young leaves are an important supplement to the feeding of livestock and certain wildlife [3]. It also provides firewood and handicrafts, shade and utilities in traditional medicine [4]. One of the most abundant and characteristic species of the sudano-guinea savannahs of Ngaoundere [5], D. oliveri plays an important role in environment protection by carbon stock [6].

At present day, this species is under anthropogenic pressure due to savannah overexploitation by indigenous peoples, transhumants and refugee peoples [7, 8]. This anthropogenic pressure leads to a dangerous and even 
irreversible reduction if nothing is done for this agroforestry species and thus jeopardizes its conservation and sustainable management in these savannahs. However, for its important role in fodder production and carbon sequestration, the management of this plant species requires a good knowledge of its biomass and its carbon stock.

During the last ten decades, considerable research efforts have been made in estimating biomass of trees and shrubs in forest ecosystems [9-13] and weakly in sub-Saharan savannah of Africa [14-15], very little in the savannah of Ngaoundere Cameroon [16-18]. For the estimation of this woody biomass, the allometric equations were widely used to prevent the destruction of forest trees, linking different dendrometric measurements of the trees and their aboveground biomass. These allometric relationships are very important for the management of natural and artificial forest resources [19-22]. Because they offered best estimation of woody biomass which is also an important variable in research of carbon emission [22, 23]. Therefore, choosing a suitable model for the development of allometric equation is important in forest and environmental sciences [23, 24].

The logarithmic model is frequently used [25] with a general equation in the form of $\mathrm{B}=\mathrm{aD}^{\mathrm{b}}$ (commonly presented as a logarithmic form) where $\mathrm{B}$ is the biomass, $\mathrm{D}$ the diameter at breast height of the tree, $a$ and $b$ are the regression coefficients. Furthermore, there are two (2) or three (3) independence explanatory variables in the allometric relationships for estimating tree biomass. In most of study, the diameter at breast height of the tree has been used as the same explanatory and independent variable in the allometric equation [26-29]. Therefore, the integration of other explanatory variables such as tree height $(\mathrm{H})$ sometime ensures greater accuracy of the allometric equation for some species [30-32]. Some allometric equations were developed in the savannah of Africa from various tropical species [3334]. It is clear that woody species are different mainly by allometry because of their different density and the stem shape. That is why, the development of specific allometric equations is essential for accuracy in estimating the carbon stock for each important species and each ecosystem. The aim of this study is the development of mono-specific allometric equations to accurately estimate biomass of the Daniellia oliveri and to deduce the ratio between the above and above-ground biomass in the sudano-guinea savannah of Cameroon.

\section{Materials and Methods}

\subsection{Study Site}

The study was carried out in Dang located in between $7^{\circ}$ $25^{\prime} 127^{\prime \prime}$ of the North latitude and 13'33'130" of the East longitude and $1081 \mathrm{~m}$ of altitude asl. The area belongs to Adamawa's sudano-guinea savannah, which constitutes a vast plateau located between the $6^{\text {th }}$ and $8^{\text {th }}$ degree of latitude North and between the $11^{\text {th }}$ and $15^{\text {th }}$ degree of longitude East. This region covers approximately $72,000 \mathrm{~km}^{2}$, with an average altitude of about $1000 \mathrm{~m}$ and occupies practically the center of Cameroon. The climate is humid sudano-guinea type [35], with a unimodal rainfall distribution. Mean annual rainfall is about $1500 \mathrm{~mm}$. The rainy season extends from July to September and dry season stretches from November to March. Mean annual temperature is $23^{\circ} \mathrm{C}$ and mean relative annual humidity is $65 \%$ [36]. While Ferralitic soils are the dominant types [37], with rich clay (40 à 60\%), low organic matter (less than 1\%), low soil exchange capacity from 15 to $20 \mathrm{meq} / 100 \mathrm{~g}$ and the $\mathrm{pH} 4.7$ to 5.6 [38]. Vegetation of Adamawa is a humid savannah type, consisting of shruby and woody savannahs. These savannahs originally populated with Daniellia oliveri and Lophira lanceolata [5]. There are also hydromorphic meadows that are sometimes inundated and contain Hypparhenia rufa, forest galleries with Syzygium guineense var. guineense and Berlinia grandifolia, fallow lands and savannahs, occasionally used as grazing lands which are composed of Acacia hockii, Afzelia Africana [5]. Now, this vegetation is much reduced under the influence of zoo-anthropic factors such as wild fires and rearing [38, 39]. Agriculture is still traditional. Livestock remains the main economic activity practiced by the more than $20 \%$ of the rural population. Other activities like hunting, fishing and crafts are practiced at artisan level in the region. The most relevant problems in the region include the permanent decline soil fertility, damages by Striga on cereals and termites on crops.

\subsection{Sampling and Data Collection}

After the authorization $n^{\circ}$ 263/ASAA/DRFOF/AD/SRF of the regional Delegate of the Ministry of Forestry of Wildlife (MINFOF), seventeen (17) individual trees of Daniellia oliveri with various diameter at breast height $(\mathrm{DBH})$, and total height $(\mathrm{H})$ were sampled in the Ngaoundere Savannah. Sample trees were selected purposively, avoiding suppressed or sick trees or those with broken tops, hollows, or other damages. These sampled individuals were distributed in the three diameter classes defined by Mamadou [16] and Ahmadou [17], at the rate of six (6) individuals for the small diameter classes $(5-15 \mathrm{~cm})$, six (6) individuals for the intermediate diameter classes $(15-25 \mathrm{~cm})$ and five (5) individuals for the large diameter classes $(25-40 \mathrm{~cm})$. The trees were felled as close to ground level as possible and after felling, each tree was separated into trunk, branches and leaves, based on the method described by Picard et al. [41]. The root excavation was made by 11 individual trees in which 4 from the small diameter classes, 3 from the intermediate diameter classes and 4 of the large diameter classes. The fresh biomass of each compartment weighed using a scale. To obtain the dry weight, three samples of each compartment and each tree were collected. In the laboratory, samples of stems, branches and roots were oven-dried at a constant temperature of $105^{\circ} \mathrm{C}$ and leaves at $75^{\circ} \mathrm{C}$ to a constant weight after 72 hours. The water content (WC) in the various compartments (stem, branches, leaves and roots) was determined after drying of the samples using the formula by $\mathrm{WC}(\%)=((\mathrm{FM}-\mathrm{DM}) / \mathrm{DM}) * 100$, with $\mathrm{WC}$ is the water 
content of the sample, FM and DM are respectively the fresh and dry mass $(\mathrm{Kg})$ of the sample. From the water content of the sample, the total dry mass (TDM) of each compartment has been calculated using the following formula, TDM $=100$ * TFM/(100 + WC), with TFM and TDM are respectively the total fresh and dry mass $(\mathrm{Kg})$. The total dry mass of each tree was estimated by adding the dry mass of the various compartments of the trees.

\subsection{Data Analysis}

The allometric equations have been established between the physical parameters of the tree such as diameter (D) and height $(\mathrm{H})$, and tree biomass [42]. The simple allometric equation was generally written using the power curve [41, $43,44]$ in the form (1):

$$
\mathrm{y}=\mathrm{ax}{ }^{\mathrm{b}}
$$

where $\mathrm{Y}$ is the dependent variable and $\mathrm{X}$ is the independent variable, and a the coefficient and $\mathrm{b}$ the allometric constant. To take into account the heteroscedasticity of data [12, 45], the formula is often linearized by using the logarithms [41], as follows (2):

$$
\operatorname{Ln}(y)=\operatorname{Ln}(a)+b \operatorname{Ln}(x)
$$

where $\operatorname{Ln}(\mathrm{a})$ and $\mathrm{b}$ are the intercept and slope of the regression line, respectively. The $\operatorname{Ln}(\mathrm{a})$ and $\mathrm{b}$ are obtained by the method of least squares. In this study, the allometric relationships of the biomass and different dimensions such as $\mathrm{D}, \mathrm{D}^{2} \mathrm{H}$, were also established using following equations (3 to 5):

$$
\begin{gathered}
\operatorname{Ln}(B)=a+b^{*} \operatorname{Ln}(D) \\
\operatorname{Ln}(B)=a+b * \operatorname{Ln}\left(D^{2} H\right) \\
\operatorname{Ln}(B)=a+b * \operatorname{Ln}(D)+c * \operatorname{Ln}(H)
\end{gathered}
$$

Where $\mathrm{B}$ is the biomass $(\mathrm{kg}), \mathrm{D}$ and $\mathrm{H}$ are respectively the tree diameter and total height $(\mathrm{m}), \mathrm{a}, \mathrm{b}$ and $\mathrm{c}$ are the coefficient of regression.

The logarithmic transformation of data generally leads a bias in the biomass estimation [20,46]. A correction is therefore necessary and consisted to multiply the estimated biomass by a correction factor which was calculated as follows: $\mathrm{CF}=\exp \left(\mathrm{RSE}^{2} / 2\right)$ [45, 47]; $\mathrm{CF}$ is the number always high to 1 . Some criteria were used to select the best predictive model when calculated. In addition to the coefficient of determination adjusted $\left(\mathrm{R}^{2} \mathrm{aj}\right)$ and the value of the statistic signification $(\mathrm{P})$, the residual standard error (RSE) and the Akaike information criteria (AIC) were calculated. RSE represents the standard deviation between the observed value and its prediction. The Akaike information criterion is a measure of the quality of the model used for the set of data considered. It allows to compare several models and to make the selection of the best model. $\mathrm{AIC}=-2 \mathrm{Ln}(\mathrm{L})+2 \mathrm{p}$, where $\mathrm{p}$ is the number of parameters in the model and $\mathrm{L}$ the maximum likelihood. These criteria make possible to judge the goodness of the model's fit; more the last criteria are low, best will be the model [20]. Statistical analysis were performed with excel 2016 and Ri 3863.1 .2 software.

\section{Results}

\subsection{Diameter, Height and Biomass Distributions}

Stand diameter and height varied from 7.54 to $34.49 \mathrm{~cm}$ and from 5 to $10.5 \mathrm{~m}$, with average of $19 \mathrm{~cm}$ and $7.40 \mathrm{~m}$ respectively (Table 1). Aboveground biomass (AGB) and below ground biomass (BGB) ranged from 19.29 to 749.87 and from 6.79 to $103.85 \mathrm{~kg}$ respectively with respective average of 185.02 and $47.53 \mathrm{~kg}$. The biomass accumulated in roots represented $20.44 \%$ of the total biomass. For the compartments, the leaf biomass ranges from 5.03 to 31.87 $\mathrm{kg}$, that of the branches from 5.66 to $464.39 \mathrm{~kg}$ and that of the stems from 7.15 to $188.20 \mathrm{~kg}$, with the respective averages of $23.02 \mathrm{~kg}, 100.84 \mathrm{~kg}$ and $61.16 \mathrm{~kg}$. The branches accumulate more biomass than the other compartments with a rate of $54.50 \%$ of the above-ground biomass, followed by stems $(33.06 \%)$.

Table 1. Rank of diameter at breast height (D), height (H), and compartment biomass of D. oliveri from field survey calculation in Ngaoundere savannahs of Cameroon.

\begin{tabular}{lllllll}
\hline Items & D $(\mathbf{c m})$ & H $(\mathbf{m})$ & \multicolumn{2}{c}{ Compartments } & \multicolumn{2}{c}{ BGB (kg) } \\
\hline & & & LB (kg) & BB (kg) & SB (kg) \\
\hline Average & 19.25 & 7.40 & 23.02 & 100.84 & 61.16 & 185.02 \\
STDEV & 7.60 & 1.90 & 25.05 & 119.90 & 51,96 & 192.68 \\
Minimum & 7.54 & 5.00 & 5.03 & 5.66 & 7.15 & 19.29 \\
Maximum & 34.49 & 10.50 & 31.87 & 464.39 & 188.20 & 73.09 \\
\hline
\end{tabular}

Leaf biomass (LB), branch biomass (BB), stem biomass (SB), aboveground biomass (AGB) and Bolow ground biomass (BGB).

\subsection{Allometric Equations}

Three models of allometric equation were developed for any compartment, with 17 individual tree for the aboveground biomass and 11 individual trees for the below ground biomass. The allometric relationships of biomass of different compartments to diameter and height of $D$. oliveri were positive and significant $(\mathrm{P}<0.001)$ with the high coefficient of determination adjusted ranged from 0.828 to 0.962 (Table 2). Regression coefficients ( $a, b$ and $c$ ) varied from -4.218 to -2.072 , from 0.744 to 2.701 and from 0.128 to 0.382 respectively for $\mathrm{a}, \mathrm{b}$ and $\mathrm{c}$. These coefficients differed among 
compartments for the same model. The model taking into account only the diameter as the physical parameter of the tree (3) was significant $(p<0,001)$ for each of the four compartments of trees, with the coefficient of determination varying between 0.836 and 0.962 . These high adjusted coefficients of comparison with those of the other 2 models (4 and 5) showed that more than $80 \%$ of these relationships were explained by the single diameter.

Table 2. Parameters of adjustments between biomass ( $\mathrm{kg}), \mathrm{DBH}(\mathrm{cm})$ and height $(\mathrm{m})$ the individuals of Daniellia oliveri in the savannahs of Ngaoundere, Cameroon.

\begin{tabular}{|c|c|c|c|c|c|c|c|c|}
\hline Allometric models & $\mathbf{A}$ & b & $\mathbf{C}$ & $\mathbf{R}^{2}$ adjusted & RSE & $\mathbf{N}$ & CF & AIC \\
\hline \multicolumn{9}{|l|}{ Leaf biomass } \\
\hline $\ln (\mathrm{B})=\mathrm{a}+\mathrm{b} \ln (\mathrm{D})$ & $-2.692(0.60)$ & $1.883(0.20)$ & & 0.836 & 0.365 & 17 & 1.068 & 17.870 \\
\hline $\ln (B)=a+b \ln \left(D^{2} H\right)$ & $-3.030(0.63)$ & $0.744(0.08)$ & & 0.836 & 0.364 & 17 & 1.068 & 17.838 \\
\hline $\ln (\mathrm{B})=\mathrm{a}+\mathrm{b} \ln (\mathrm{D})+\mathrm{c} \ln (\mathrm{H})$ & $-2.887(0.70)$ & $1.689(0.39)$ & $0.382(0.66)$ & 0.828 & 0.373 & 17 & 1.072 & 19.476 \\
\hline \multicolumn{9}{|l|}{ Branch biomass } \\
\hline $\ln (\mathrm{B})=\mathrm{a}+\mathrm{b} \ln (\mathrm{D})$ & $-3.772(0.56)$ & $2.701(0.19)$ & & 0.923 & 0.342 & 17 & 1.060 & 15.706 \\
\hline $\ln (\mathrm{B})=\mathrm{a}+\mathrm{b} \ln \left(\mathrm{D}^{2} \mathrm{H}\right)$ & $-4,218(0.63)$ & $1.063(0.08)$ & & 0.914 & 0.362 & 17 & 1.067 & 17.582 \\
\hline $\ln (\mathrm{B})=\mathrm{a}+\mathrm{b} \ln (\mathrm{D})+\mathrm{cln}(\mathrm{H})$ & $-3,889(0.66)$ & $2.583(0.37)$ & $0.229(0.62)$ & 0.918 & 0.353 & 17 & 1.064 & 17.545 \\
\hline \multicolumn{9}{|l|}{ Stem biomass } \\
\hline $\ln (\mathrm{B})=\mathrm{a}+\mathrm{b} \ln (\mathrm{D})$ & $-2.663(0.34)$ & $2.218(0.11)$ & & 0.955 & 0.210 & 17 & 1.022 & -0.852 \\
\hline $\ln (\mathrm{B})=\mathrm{a}+\mathrm{b} \ln \left(\mathrm{D}^{2} \mathrm{H}\right)$ & $-3.023(0.41)$ & $0.872(0.05)$ & & 0.944 & 0.235 & 17 & 1.028 & 2.973 \\
\hline $\ln (\mathrm{B})=\mathrm{a}+\mathrm{b} \ln (\mathrm{D})+\mathrm{cln}(\mathrm{H})$ & $-3.889(0.40)$ & $2.583(0.23)$ & $0.229(0.38)$ & 0.918 & 0.353 & 17 & 1.064 & 17.545 \\
\hline \multicolumn{9}{|l|}{ Above ground Biomas } \\
\hline $\ln (B)=a+b \ln (D)$ & $-2.089(0.34)$ & $2.374(0.11)$ & & 0.962 & 0.207 & 17 & 1.021 & -1.291 \\
\hline $\ln (\mathrm{B})=\mathrm{a}+\mathrm{b} \ln \left(\mathrm{D}^{2} \mathrm{H}\right)$ & $-2.477(0.40)$ & $0.934(0.05)$ & & 0.951 & 0.234 & 17 & 1.027 & 2.755 \\
\hline $\ln (\mathrm{B})=\mathrm{a}+\mathrm{b} \ln (\mathrm{D})+\mathrm{c} \ln (\mathrm{H})$ & $-2.178(0.40)$ & $2.284(0.22)$ & $0.175(0.38)$ & 0.959 & 0.213 & 17 & 1.023 & 0.451 \\
\hline \multicolumn{9}{|l|}{ Below ground biomass } \\
\hline $\ln (\mathrm{B})=\mathrm{a}+\mathrm{b} \ln (\mathrm{D})$ & $-2.072(0.53)$ & $1.920(0.18)$ & & 0.918 & 0.265 & 11 & 1.035 & 5.826 \\
\hline $\ln (\mathrm{B})=\mathrm{a}+\mathrm{b} \ln \left(\mathrm{D}^{2} \mathrm{H}\right)$ & $-2.366(0.58)$ & $0.751(0.07)$ & & 0.912 & 0.274 & 11 & 1.038 & 6.578 \\
\hline $\ln (\mathrm{B})=\mathrm{a}+\mathrm{b} \ln (\mathrm{D})+\mathrm{c} \ln (\mathrm{H})$ & $-2.129(0.67)$ & $1.850(0.47)$ & $0.128(0.81)$ & 0.908 & 0.281 & 11 & 1.040 & 7.791 \\
\hline
\end{tabular}

Coefficient of regression model $(a, b$ and $c)$, specimen number $(N)$, coefficient of determination adjusted $\left(\mathrm{R}^{2} \mathrm{adj}\right)$, correction factor $(\mathrm{CF})$, residual standard error (RSE) and Akaike information criteria (AIC).

By integrating the height of the tree in both model of 4 and 5 , no improvement was obtained in the precision with the equations predicting the biomass of branches, trunk, roots and the total, except that of leaves. For this last compartment, the equation 4 , integrating the diameter squared multiplied by the height $\left(D^{2 *} \mathrm{H}\right)$ in the fit, of the form $\operatorname{Ln}(\mathrm{Bf})=\mathrm{a}+\mathrm{b}^{*} \mathrm{Ln}$ $\left(\mathrm{D}^{2} \mathrm{H}\right)$, improved the model. The coefficient of determination adjusted of this model was high (0.836) and its residual standard error (RSE) was lower (0.364) than the model taking into account only the diameter $(0.365)$. For the other compartment (branches, trunks, roots and their total), the coefficient of determination adjusted to the model taking into account the diameter and the height were lower than those of the model taking into account only the diameter.

To select best model predicting the biomass of each compartment in addition to the coefficient of determination adjusted ( $R^{2}$ adj), the residual standard error (RSE) and the Akaike value (AIC) which enable to evaluate the accuracy of the models have been taken into account. These coefficients of determination adjusted ( $\left.\mathrm{R}^{2} \mathrm{adj}\right)$ of the 5 best models selected to each of the compartment and the total biomass were higher, their RSE and their AIC were lower than the value of their models. These best equations were presented in table 2 and the figures 1 and 2 .
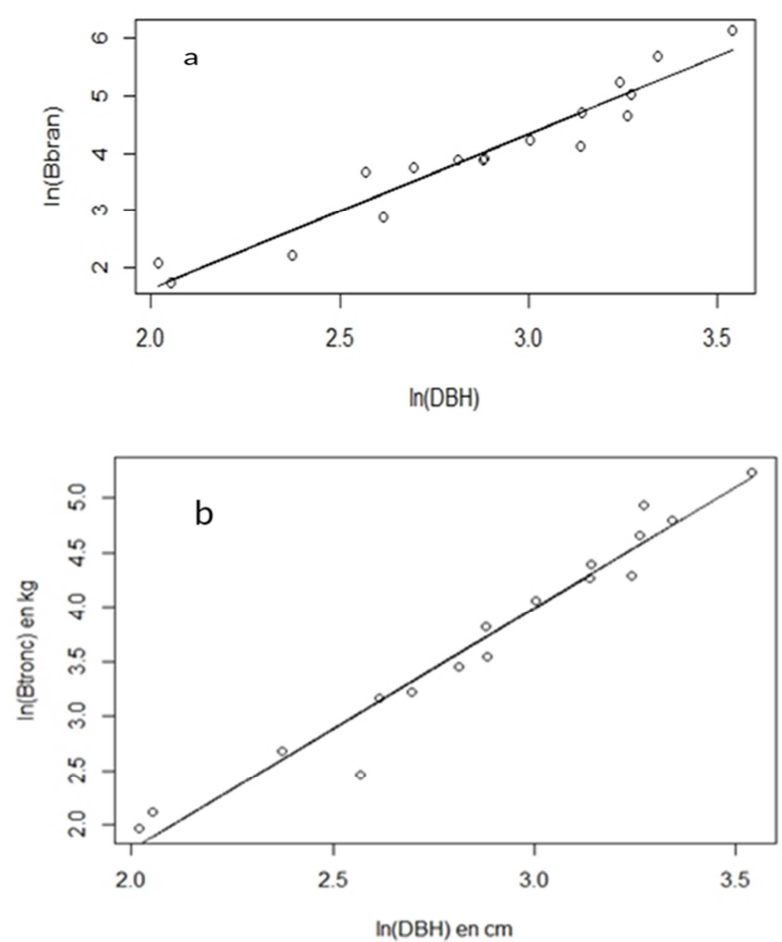

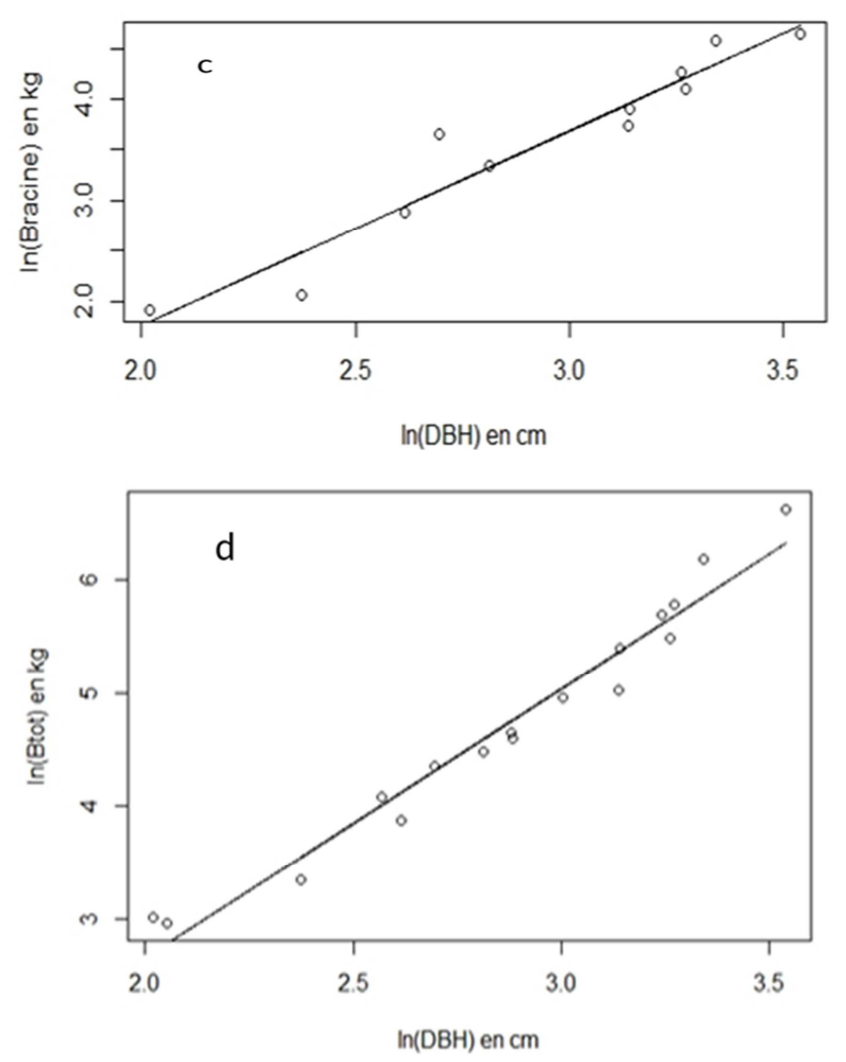

Figure 1. Linear regressions between diameter and biomasses of branches (a), stems (b), roots (c) aboveground biomass (d).

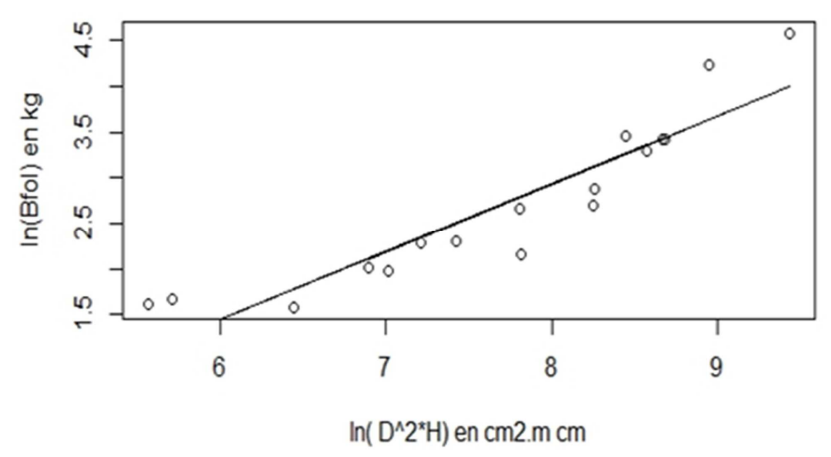

Figure 2. Linear regressions between $\left(D^{2} H\right)$ and biomasses of leaves.

\subsection{Relationship Between the Root and Above-Ground Biomass}

The relationship between the root biomass and other tree compartment biomass were determined (Figure 3). The ratios of these relations varied from 0.28 to 2.14 and showed that the biomass of $D$. oliveri represented an average of $28 \%$ of the total above-ground biomass and $214 \%$ of leaves. The root biomass as a function of total biomass has been adjusted to a logarithmic function (Figure 4) and the coefficient of determination was 0.916 . That means that it exists a positive and significant relationship $\left(\mathrm{R}^{2}=0.9163, \mathrm{P}<0.05\right.$ and $\left.\mathrm{n}=11\right)$ between the root biomass and the total above-ground one.

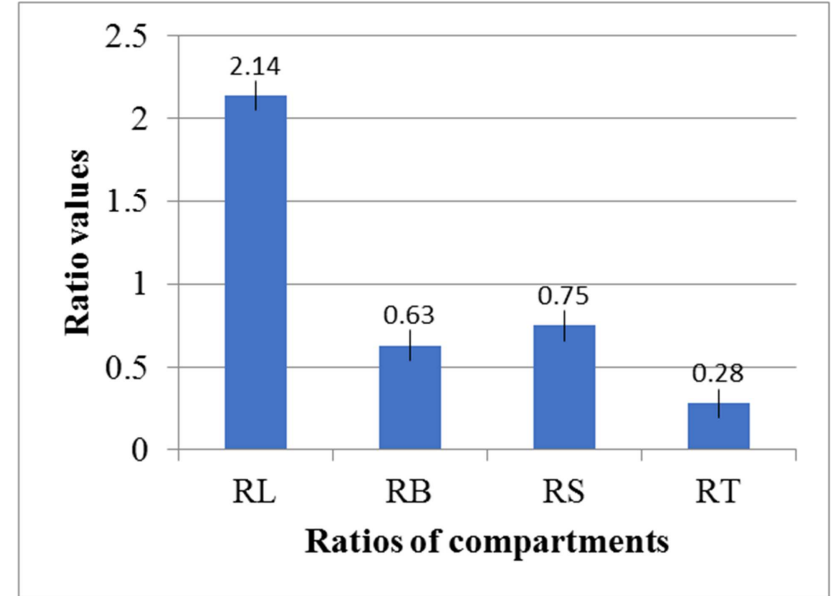

Figure 3. Ratio between root biomass and leaf biomass (RL), branch biomass (RB), stem biomass (RS) and trunk biomass (RT).

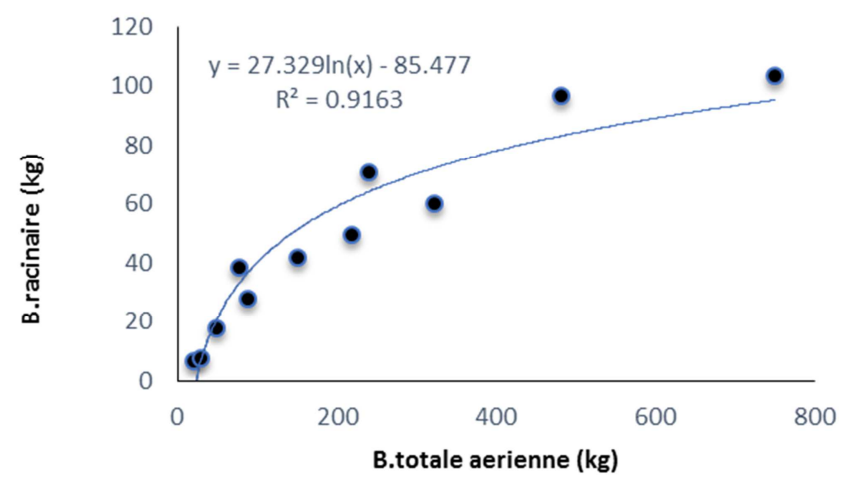

Figure 4. Nonlinear regression between root biomass and above ground biomass.

\subsection{Relation Between Diameter and Height}

The relation between the height and diameter of trees are better adjusted to the linear function (Figure 5). This correlation between these two variables is positive and significant with a coefficient of determination of 0.92 and sample number (n) of 12. The tree height was therefore linked to the diameter in the savannah of Ngaoundere for $D$. oliveri, and increased linearly with the diameter of trees. The bias was very low.

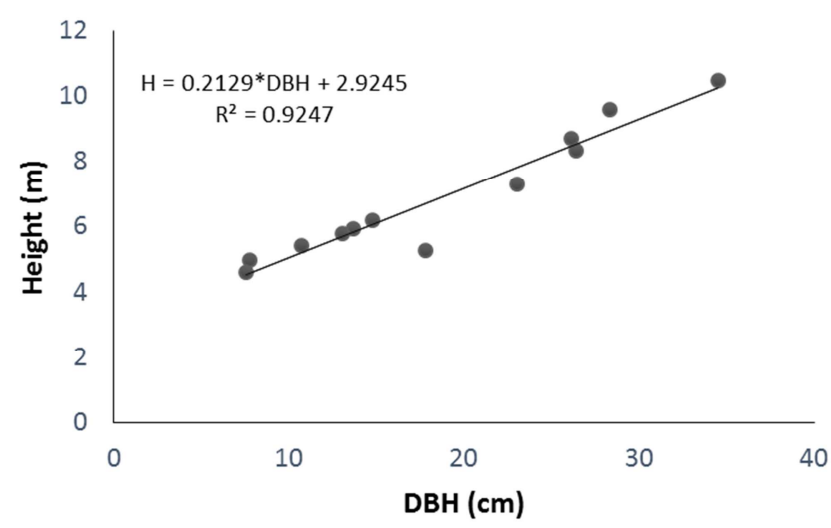

Figure 5. Relationship between height and DBH of Daniellia oliveri. 


\section{Discussion}

The study established allometric equations for the estimation of the above- and below-ground biomass in the diameter range between 5 and $40 \mathrm{~cm}$. The species characterized the sudano-guinea savannah of Adamawa by its abundance and its frequency [5]. The determination of specific equation of this species is important for the accurate determination of its production, the accurate estimation of the carbon stock and the sustainable management of its population. In fact, according to Bougnounou et al. [33], the establishment of allometric equation for biomass predicting by species makes overall estimate biomass of a woody stand smaller. According to Navar et al. [15], an allometric equation by species improved to $12.5 \%$ the efficiency of biomass estimation against a global model of woody community.

Allometric equation were developed from the 2 physical variables which are the tree diameter and height, taking into account the Akaike information criteria and the residual standard error [20]. And also 5 models have been selected. The model of the total biomass of equation 3, taking into account the diameter can be considered as the best model. Their AIC and RSE values were lower and its coefficient of determination adjusted was higher. It has shown that the tree height did not significantly influence the biomass. The height was in fact the function of the diameter [20, 48]. This result was similar to that of Bagnoud and Kouyate [49] who have worked on D. oliveri in Mali. As the total biomass, the best model of branches, trunks and root biomass was the equation 3 model which was not influenced by the height as found by Traore et al. [50]. On the other hand, the best equation for the estimation of leaf biomass was obtained with the model of equation 4 , integrating the tree diameter squared multiplied by the height $\left(\mathrm{D}^{2} \mathrm{H}\right)$, with $\mathrm{RSE}=0.364 ; \mathrm{AIC}=17.836$ and $\mathrm{R}^{2} \mathrm{adj}=0.836$. These results were similar to those of Mamadou Laminou [16] who has shown that the best model for predicting leaves biomass of eight (8) plant species of the wet Ngaoundere savannah was the equation 4 model with $\mathrm{RSE}=0.53, \mathrm{AIC}=43.3$ and $\mathrm{R}^{2} \mathrm{adj}=0.640$. Contrary, these results differed from those of Djomo et al. [12] and Vahedi et al. [51].

The number of sample and diameter range in the development of allometric models found in literature were variable and take into account the resources, site study and time allocated to the study [41]. In fact, Brown [10] and Chave et al. [20] used more than 100 sample trees to establish allometric models. However Peltier et al. [52], Lawarnou et al. [53], Ebuy et al. [54] established their models with less than 20 sample trees. In our study, the sample trees (17 trees) used was low but acceptable.

The ratio established in our study was not in adequacy with other results found in literature like those of Poupon [55] and Eumont [56]. We have not found the results for $D$. oliveri in particular, but for wood in general, GIEC [57] has determined a ratio of 0.24 which was not far from the value found in our study. The small difference observed could be due, on one hand to the architecture form of trees [44] of species used in this study and on the other hand to the environment condition which differed in the two studies.

The value of the correlation between the total aboveground biomass and those of the root could be explained by a good balance of development and physiological growth of $D$. oliveri between the above- and below-ground compartments, despite all this anthropogenic pressures exerted on this species in the sudano-guinea savannah of Ngaoundere [58]. So, we can say that the increase of the biomass of the root was strongly linked to that of the above-ground.

\section{Conclusion}

This study established the mono-specific allometric models for predicting biomass of Daniellia oliveri in the sudano-guinea savannah of Ngaoundere from 17 tree samples. The allometric models predicting the biomass of branches, stems, roots and above-ground were developed with diameter as tree physical parameter, while for the accuracy of allometric model predicting the biomass of leaves, tree height need to be integrated to model as an independent variable with tree diameter. These results would contribute to improve the estimation of carbon stock of Daniellia oliveri stands in the sudano-guinea savannahs of Ngaoundere. While it may also contribute to the general debate regarding the development and use of allometric equations for estimating biomass and carbon stock in African savannah as a whole, it also adds vital data in this regard for Adamawa savannahs for which such methods have not yet been developed.

\section{Acknowledgements}

We thank the reviewers for their contribution to improve this paper by their observations and suggestions.

\section{References}

[1] Arbonnier, M. 2002. Arbres, arbustes et lianes des zones sèches d'Afrique de l'Ouest. Montpellier: Cirad éditions.

[2] Mapongmetsem, P. M. 2005. Phénologie et apports au sol des substances biogènes de la litière des feuilles de fruitiers sauvages des savanes soudano-guinéennes. Thèse de Doctorat d'Etat, Université de Yaoundé I, Cameroun. 268p.

[3] Von Maydell, H. J. 1990. Arbres et arbustes du sahel: leurs caractéristiques et leurs utilisations. Weikersheim, GTZ.

[4] Gautier, D., Hautdidier, B., Ntoupka, M., Onana, J., Perrot N. \& Tapsou, T. 2002. Fiches techniques des arbres utiles aux paysans du Nord Cameroun. Caractéristiques de l'arbre, ce qu'en font les paysans et ce qu'ils pourraient en faire. 106p.

[5] Letouzey, R. 1968. Etude phytogéographique du Cameroun. Ed. Le chevalier (Paris), 551p.

[6] Tchobsala 2011. Impact des coupes de bois sur la végétation naturelle de la zone périurbaine de Ngaoundéré (Adamaoua). Thèse de Doctorat/Ph. D, Université de Yaoundé I, Cameroun $204 \mathrm{p}$. 
[7] Mapongmetsem, P. M. 2006. Domestication of Vitex madiensis in the Adamaoua highlands of Cameroon: phenology and propagation. Akdeniz Universitesi Ziraa Fakultesi Dergisi. 19 (2): 269-278.

[8] Ibrahima, A., Mapongmetsem, P. M. \& Hassan, M. 2006. Influence de quelques facteurs zoo-anthropiques sur la phytodiversité ligneuse des savanes soudano-guinéennes de l'Adamaoua, Cameroun. Annales De la Faculté des Sciences, Université de Yaoundé I, Série Sci. de la Nat. et de la Vie. 36 (3): 65-85.

[9] Mahmood, H., Siddique, M. R. H., Costello, L., Birigazzi, L., Abdullah, S. M. R., Henry, M., Siddiqui, B. N., Aziz, T., Ali, S., Al Mamun, A., Forhad, M. I. K., Akhter, M., Iqbal, Z. \& Mondol, F. K. 2019. Allometric models for estimating biomass, carbon and nutrient stock in the Sal zone of Bangladesh. iForest. 12: 69-75.

[10] Brown, S. 1997. Estimating Biomass and Biomass Change of Tropical Forests: a Primer. FAO Forestry Paper no134. FAO, Rome. 45, 106.

[11] Ibrahima, A., Schmidt, P., Ketner, P. \& Mohren, G. J. M. 2002. Phytomasse et cycle des nutriments dans la forêt tropicale dense humide du sud Cameroun. Tropenbos Cameroon Documents 9. The Tropenbos Cameroon Programme.

[12] Djomo, A. N., Ibrahima, A., Saborowski, J. \& Gravenhorst, G. 2010. Allometric Equations for Biomass Estimations in Cameroon and Pan Moist Tropical Equations Including Biomass Data from Africa. Forest Ecology and Management. 260: 1873-1885.

[13] Laminou Manzo, O., Moussa, M., Issoufou, HBA, Abdoulaye, D., Morou, B., Youssifi, S., Mahamane, A. \& Paul, R. 2015. Equations allométriques pour l'estimation de la biomasse aérienne de Faidherbiaalbida (Del.) Achev dans les agrosystèmes d'Aguié, Niger. International Journal of Biological and Chemical Sciences. 9 (4): 1863-1874.

[14] Mensah, S., Veldtman, R. \& Seifert, T. 2017. Allometric Models for Height and Aboveground Biomass of Dominant Tree Species in South African Mistbelt Forests. Southern Forests: A Journal of Forest Science. 79: 19-30.

[15] Návar, J, Méndez, E, Nájera, A, Graciano, J, Dale, V. \& Parresol, B. 2004. Biomass equations for shrub species of Tamaulipanthornscrub of North-eastern Mexico. Journal of Arid Environment. 59: 657-74.

[16] Mamadou Laminou, M. A. 2014. Equations de prédiction de la Biomasse de quelques espèces ligneuses des savanes de Ngaoundéré, Cameroun. Mémoire de Master en Biologie des Organismes Végétaux, Faculté des Sciences, Université de Ngaoundéré, 51p.

[17] Ahmadou, I. 2014. Equations de l'estimation de la Biomasse des huit espèces ligneuses de savanes de Ngaoundéré, Cameroun. Mémoire de Master en Biologie des Organismes Végétaux, Faculté des Sciences, Université de Ngaoundéré, $47 \mathrm{p}$.

[18] Halilou, A. 2015. Equations de prédiction de la Biomasse de quelquesespèces ligneuses de savanes de Ngaoundéré, Cameroun. Mémoire de Master en Biologie des Organismes Végétaux, Faculté des Sciences, Université de Ngaoundéré, $54 \mathrm{p}$.

[19] Nam, V. T., Van Kuijk, M. \& Anten, N. P. R. 2016. Allometric equations for aboveground and belowground biomass estimations in an evergreen forest in Vietnam. PLoS ONE. 11 (6): 1-19.

[20] Chave, J., Rejou-Mechain M., Burquez, A., Chidumayo, E., Colgan, M. S., Delitti, W. B. C., Duque, A., Eid, T., Fearnside, P. M., Goodman, R. C., Henry, M., Martínez-Yrízar, A., Mugasha, W. A., Muller-Landau, H. C., Mencuccini, M., Nelson, B. W., Ngomanda, A., Nogueira, E. M., OrtizMalavassi, E., Pélissier, R., Ploton, P., Ryan, C. M., Saldarriaga, J. G. \& Vieilledent, G. 2014. Improved allometric models to estimate the aboveground biomass of tropical trees. Global Change Biology. 20: 3177-3190.

[21] Röhling, S., Demant, B., Dunger, K., Neubauer, M., Oehmichen, K., Riedel, T. \& Stümer, W. 2019. Equations for estimating belowground biomass of Silver Birch, Oak and Scots Pine in Germany. iForest. 12: 166-172.

[22] Nogueira, E. M., Fearnside, P. M., Nelson, B. W., Barbosa, R. I. \& Keizer, E. W. H. 2008. Estimates of forest biomass in the Brazilian Amazon: new allometric equations and adjustments to biomass from wood-volume inventories. Forest Ecology and Management. 256 (11): 1853-1867.

[23] Ketterings, Q. M., Coe, R., van Noordwijk, M., Ambagu, Y. \& Palm, C. A. 2001. Reducing uncertainty in use of allometric biomass equations for predicting above-ground tree biomass in mixed secondary forests. Forest Ecology and Management. 146: 199-202.

[24] Liepinš, J., Lazdinš, A. \& Liepinš, K. 2018. Equations for estimating above- and belowground biomass of Norway spruce, Scots pine, birch spp. and European aspen in Latvia. Scandinavian Journal of Forest Research. 33 (1): 58-70.

[25] Ter-Mikaelian, M. T. \& Korzukhin, M. D. 1997. Biomass equations for sixtyfive North American tree species. Forest Ecology and Management. 97: 1-24.

[26] Smith, A., Granhus, A. \& Rasmus, A. 2016. Functions for estimating belowground and whole tree biomass of birch in Norway. Scandinavian Journal of Forest Research. 31 (6): 568-582.

[27] Amarasing, M. D. \& Balasubrananiam, S. 1992. Net primary productivity of two mangrove forests stands on the northwest coast of Sri Lanka. Hydrobiologia. 247, 37-47.

[28] Clough, B. F., Dixon, P., \& Dalhaus, O. 1997. Allometric relationships for estimating biomass in multistemed mangrove trees. Australian Journal of Botany. 45: 1023-1031.

[29] Ong, J. E., Gong, W. K. \& Wong, C. H. 2004. Allometry and partitioning of the mangrove, Rhizophoraapiculata. Forest Ecology and Management. 188: 395-408.

[30] Suzuki, E. \&Tagawa, E. 1983. Biomass of a mangrove forest and a sedge marsh on Ishigakiisland, south Japan. Japanese Journal of Ecology. 33: 231-234.

[31] Tamai, S., Nakasuga, T., Tabuchi, R. \& Ogino, K. 1986. Standing biomass of mangrove forests in southern Thailand. Journal of Japanese Forest Society. 68 (9): 384-388.

[32] Poungparn, S., Komiyama, A., Jintana, V., Piriyauaota, S., Sangtiean, T., Tanapermpool, P., Patanaponpaiboon, P. \& Kato, S. 2002. A quantitative analysis on the root system of a mangrove, Xylocarpusgranatum Koenig. Tropics. 12: 35-42. 
[33] Bognounou, F., Sawadogo, M., Boussim, I. J. \& Guinko, S. 2008. Equations d'estimation de la biomasse foliaire de cinq espèces ligneuses soudaniennes du Burkina Faso. Sécheresse. 19 (3): 201-5.

[34] Lufafa, A., Diédhiou, I., Ndiaye, N. A. S., Séné, M., Kizito, F., Dick, R. P. Noller, J. S. 2009. Allometric relationships and peak-season community biomass stocks of native shrubs in senegal'speanuntbassin. Journal of Arid environments. 73 (3): 260-266.

[35] Suchel, J. B. La répartition des pluies et régimes pluviométriques au Cameroun, Centre de Recherches Africaines, Université fédérale du Cameroun. 1971; 29p.

[36] Carrière, M. 1989. Les communautés végétales sahéliennes en Mauritanie (Région de Kaédi), analyse de la reconstitution annuelle du couvert herbacé. Thèse de Doctorat, Université de Paris Sud Orsay, IE. M. V. T. Maisons-Alfort, CENERV., Nouakchott.

[37] Boutrais, J. 197. Les conditions naturelles de l'élevage sur le plateau de l'Adamaoua (Cameroun)", Cahiers ORSTOM, Série Sci. Hum. XV (2): 145-198.

[38] Brabant, P. \& Humbel, F. X. 1974. Notice explicative de la carte pédologique de Poli, No. 51, Carte au 1/50000e, Yaoundé.

[39] Yonkeu, S. 1993. Végétation des pâturages de l'Adamaoua (Cameroun): écologie et potentialités pastorales. Thèse de Doctorat, Université de Rennes, France, pp. 207.

[40] Mapongmetsem, P. M., Nkongmeneck, B. A., Rongoumi, G., Dongock, D. \& Dongmo, B. 2011. Impact des systèmes d'utilisation des terres sur la conservation de Vitellaria paradoxa Gaertn. (Sapotaceae) dans la région des savanes soudano-guinéennes. International Journal of Environmental Studies. 68 (6): 51-72.

[41] Picard, N., Rutishauser, E., Ploton, P., Ngomanda, A. \& Henry, M. 2015. Should Tree Biomass Allometry Be Restricted to Power Models? Forest Ecology and Management. 353: 156-163.

[42] 42] Lotfi, A. 2008. Durabilité écologique des paysages agricoles et production de bois, bocage et néobocage. Disertation, Rennes: Université de Rennes 1.

[43] Nelson, B. W., Mesquita, R., Pereira, J. L. G., de Souza, S. G. A., Batista, G. T. \& Couto, L. B. 1999. Allometric Regressions for Improved Estimate of Secondary Forest Biomass in the Central Amazon. Foresr Ecology and Management. 117: 149-167.

[44] Henry, M., Picard, N., Trotta, C., Manlay, R., Valentini, R., Bernoux, M. \& Saint-André, L. 2012. Estimating tree biomass of sub-Saharan African forests: a review of available allometric equations. Silva Fennica. 45 (3B): 477-569.

[45] Djomo, A. N., Picard, N., Fayolle, A., Henry, M., Ngomanda, A., Ploton, P., McLellan, J., Saborowski, J., Ibrahima, A. \& Lejeune, P. 2016. Tree Allometry for Estimation of Carbon Stocks in African Tropical Forests. Forestry. 89: 446-455.

[46] Parresol, B. R. 1999. Assessing Tree and Stand Biomass: A Review with Examples and Critical Comparisons. Forest Science. 45: 573-593.

[47] Djomo, N. A. \& Chimi, D. C. 2017. Tree Allometric
Equations for Estimation of Above, Below and Total Biomass in a Tropical Moist Forest: Case Study with Application to Remote Sensing. Forest Ecology and Management. 391: 184193.

[48] 48] Fayolle, A., Doucet, J. L., Bourland, N. \& Lejeune, P. 2013. Tree allometry in Central Africa: Testing the validity of pantropical multi-species allometric equations for estimating biomass and carbon stocks. Forest Ecology and Management. 305: 29-37.

[49] Bagnoud, N. \& Kouyaté, A. M. 1996. Estimation du volume de bois des formations savanicoles de la zone soudanienne (cercle de Sikasso) -Tarifs de cubage pour quelques espèces ligneuses et relations dendrométriques pour le bois de feu. Document Appui à la Recherche Forestière de Sikasso (ARFS) 96/3, Ministère du développement rural et de l'environnement, Institut d'Économie Rurale, pp. 86-88.

[50] Traoré, S., Djomo, A. N., N'guessan, A. K., Coulibaly, B., Ahoba, A., Gnahoua, G. M., N'guessan, É. K., Adou Yao, C. Y., N'Dja, J. K. \& Guédé N. Z. 2018. Stand Structure, Allometric Equations, Biomass and Carbon Sequestration Capacity of Acacia mangium Wild. (Mimosaceae) in Côte d'Ivoire. Open Journal of Forestry. 8: 42-60.

[51] Vahedi, A. A., Mataji, A., Babayi-kafaki, S., Eshaghi-rad, J., Hodjati, S. M. \& Djomo, A. N. 2014. Allometric equation for predicting aboveground biomass of beech-hornbeam stands in the Hyrcanian forests of Iran. Journal of Forest science. 60 (6): 236-246.

[52] Peltier, R., Forkong, C. N., Mama, F., Ntoupka, M., Manlay, R., Henry, M. \& Morillon, V. 2007. Évaluation du stock de carbone et de la productivité en bois d'un parc à karités du Nord Cameroun. Revue Bois et Forêts des Tropiques. 294 (4): 12.

[53] Larwanou, M., Yemshaw, Y. \& Saâdou, M. 2010. Prediction models for estimating foliar and fruit dry biomasses of five Savannah tree species in the West African Sahel. International Journal of Biological and Chemical Sciences. 4 (6): 22452256.

[54] Ebuy, J., Lokombé Dimandja, J. P., Ponette, Q., Sonwa, D. \& Picard, N. 2011. Biomass equation for predicting tree aboveground biomass at Yangambi, RDC. Journal of Tropical Forest Science. 23 (2): 125-132. DOI: 10.1088/17489326/3/4/045011.

[55] Poupon, H. 1985. Structure et dynamique de la strate ligneuse d'une steppe sahélienne au Nord du Sénégal. Thèse Science Naturelles, Université de Paris Sud, ORSAY. Travaux et Document de L'ORSTOM, 351p.

[56] Eumont, E. 2011. Analyse de la biomasse racinaire d'Abies concolor en Sierra Nevada grâce à la technologie LiDAR et au traitement d'images. Mémoire de master Nancy-université $26 \mathrm{p}$.

[57] GIEC. 2006. Guide pour l'inventaire national des gaz à effet de serre, agriculture, foresterie et autre usage des terres. Institute for Global Environnemental Strategies, Japon. 4: 4652 .

[58] Tchobsala \& Mbolo, M., 2013. Characterization and impact of wood logging on plant formations in Ngaoundéré District, Adamawa Region, Cameroon. Journal of Ecology and the Natural Environment. 5 (10): 265-277. 